\title{
Perencanaan Fasilitas Rekreasi Pada Kolam Retensi Di Kelurahan Muktiharjo Kidul, Semarang (Dalam Desain Detail Perancangan Ruang Publik)
}

\author{
The Planning of Recreation Facilities On Retention Basin in Muktiharjo Kidul, \\ Semarang (Detail Design of Public Space)
}

\author{
Kirana Prameswari Miolo ${ }^{1}$ \\ Universitas Diponegoro, Semarang, Indonesia \\ Djoko Suwandono² \\ Universitas Diponegoro, Semarang, Indonesia
}

\begin{abstract}
Abstrak: Penelitian dari perencanaan ini bertujuan untuk meningkatkan fungsi dari kolam retensi yang hanya bersifat fungsional yaitu untuk pengendali banjir. Peningkatan fungsi tersebut akan direncanakan dengan mengembangkan kolam retensi sebagai ruang publik serta fasilitas rekreasi yang dapat meningkatkan daya tarik bagi masyarakat serta wisatawan lokal. Metode penelitian yang digunakan adalah kuantitatif dan kualitatif karena bertujuan untuk mencari pola yang tepat dalam perencanaan fasilitas rekreasi pada kolam retensi. Pendekatan yang digunakan yaitu menggunakan pendekatan kualitatif karena pendekatan tersebut dilakukan dengan observasi secara naturalistik. Hasil akhir yang ingin dicapai berupa kajian penentuan lokasi kolam retensi. Selain itu pembangunan fasilitas rekreasi pada kolam retensi bertujuan untuk memenuhi kebutuhan masyarakat yang berada di sekitar kolam retensi akan kegiatan rekreasi. Konsep yang digunakan untuk pengembangan fasilitas rekreasi pada kolam retensi adalah Waterfront As A Public Space and Recreation. Konsep ini didukung dengan teori Waterfront Development dan juga Child Friendly Space.
\end{abstract}

Kata kunci: kolam retensi; ruang publik; fasilitas rekreasi

\begin{abstract}
This research and planning have an objective for improve the function of the retention basin thats are functional just for flood control. Improvement of the function will be planned by developing a retention basin as a public space and recreational facilities which can enhance the attractiveness of the community as wall as local tourists. The research method used quantitative and qualitative because to find the right pattern in planning of recreation facilities at retention basin. This Approach is using qualitative approach, because the implementation of this approach is used with naturalistic observation. The result from this research is study of determination of the location retention basin. The development of recreational facilities on the retention basin is to provide communities needs of recreational activities. The concept of development recreational facilities on the retention basin is waterfrront as a public space and recreation. this concept is supported by the theory of waterfront development and child friendly space.
\end{abstract}

Keywords: retension basin; public space; recreation facilities

\footnotetext{
${ }^{1}$ Korespondensi Penulis: Universitas Diponegoro, Semarang, Indonesia Email: miolokirana@gmail.com

${ }^{2}$ Korespondensi Penulis: Universitas Diponegoro, Semarang, Indonesia Email: dsuwandono@gmail.com
} 
Pendahuluan
Kelurahan Muktiharjo Kidul merupakan salah satu wilayah padat permukiman di Kota Semarang. Terdapat dua pola permukiman yang ada yaitu permukiman terencana dan permukiman swadaya. Dengan adanya permukiman padat tersebut menyebabkan banyaknya aktivitas seperti perdagangan dan jasa. Adanya pusat aktivitas tersebut tidak di dukung dengan pengembangan infrastruktur serta perawatan infrastruktur yang baik. Selain itu perubahan guna lahan yang terus terjadi menyebabkan semakin berkurangnya lahan hijau pada wilayah ini. Akibat dari permasalahan tersebut, Kelurahan Muktiharjo Kidul menjadi salah satu kawasan yang sering mengalami banjir. Genangan air yang di timbulkan apabila terjadi banjir yaitu hingga mencapai $50-100 \mathrm{~cm}$. Banjir menyebabkan terganggunya aktivitas masyarakat serta menimbulkan banyak kerugian.

Kondisi tersebut membuat pemerintah melakukan upaya dalam mengurangi permasalahan banjir dengan melakukan pembangunan kolam retensi. Rencana pembangunan kolam retensi telah dimasukkan dalam Rencana Kerja Pembangunan Daerah (RKPD 2014) Kota Semarang tahun 2014 dan sudah berjalan hingga saat ini. Namun, terdapat permasalahan dalam penentuan lokasi dari pembangunan kolam retensi tersebut. Pembangunan yang dilakukan pada zonasi campuran yaitu, permukiman serta perdagangan dan jasa menimbulkan konflik dalam proses pembangunan kolam retensi tersebut. Terdapat isu yang menyebutkan bahwa pembangunan kolam retensi di Kelurahan Muktiharjo Kidul menyalahi aturan RTRW sehingga tidak layak untuk dijadikan sebagai lokasi kolam retensi. Berdasarkan permasalahan tersebut maka diperlukan kajian terhadap lokasi pembangunan kolam retensi yang berada pada Kelurahan Muktiharjo Kidul. Dengan adanya kajian tersebut dapat menghasilkan sebuah evaluasi kesesuaian lokasi pembangunan kolam retensi.

Pada saat ini ruang-ruang publik semakin berkurang setiap waktunya. Peran ruang publik bagi masyarakat sangatlah penting, selain sebagai tata ruang lingkungan, ruang publik juga dapat mengembangkan fungsi dari kawasan. Namun adanya perkembangan kota yang cepat menyebabkan kebutuhan ruang publik menjadi berkurang dan berubah fungsinya menjadi daerah komersial seperti permukiman atau perdagangan dan jasa. Akibat adanya ketersediaan ruang publik tersebut maka perlu adanya pemanfaatan ruang publik pada kolam retensi untuk menyelesaikan permasalahan akan ketersediaan ruang publik bagi masyarakat. Dengan adanya pemanfaatan tersebut, lokasi kolam retensi selain untuk mengatasi permasalahan banjir juga dapat digunakan sebagai ruang publik dan dijadikan sebagai salah satu fasilitas rekreasi di Kelurahan Muktiharjo Kidul dan sekitarnya.

Pembangunan kolam retensi di Kelurahan Muktiharjo Kidul sudah selesai dilaksanakan, namun pengelolaannya masih bersifat fungsional dimana pembangunannya hanya sebatas untuk mengurangi permasalahan banjir saja. Oleh karena itu perlu adanya pemanfaatan ruang pada lokasi kolam retensi sehingga dapat meningkatkan fungsi dari lokasi kolam retensi. Pada Kota Semarang, terdapat bangunan pengendali banjir yang terletak di Kota Lama yaitu Polder Tawang. Pada kenyataannya pembangunan polder tawang yang berada pada daerah Kota Lama tersebut digunakan masyarakat sebagai ruang publik dan rekreasi, namun polder tawang tersebut tidak dipersiapkan oleh pemerintah menjadi sebuah ruang publik dan rekreasi. Hal ini menyebabkan ruang publik yang dibentuk oleh masyarkat tersebut menjadi tidak terkelola dengan baik. Oleh karena itu perlu adanya perancangan fasilitas rekreasi pada kolam retensi agar fungsi dari kolam retensi sebagai bangunan pengendali banjir dan sebagai fasilitas rekreasi dapat berjalan optimal bagi masyarakat.

Berdasarkan permasalahan tersebut disusunlah perancangan fasilitas rekreasi pada kolam retensi di Kelurahan Muktiharjo Kidul yang bertujuan untuk mengatasi permasalahan banjir yang dapat meningkatkan fungsi kawasan sekitarnya. Oleh karena itu dibutuhkan proses perancangan dan pembangunan yang tepat, mulai dari rancangan site kawasan perancangan kolam retensi hingga konsepsi detail perancangan untuk fasilitas rekreasi yang semua pembangunannya tersebut mempertimbangkan permasalahan lingkungan. Melalui perancangan tersebut diharapkan dapat mengurangi permasalahan banjir serta dapat meningkatkan fungsi kawasan di Kelurahan Muktiharjo Kidul dan sekitarnya. 
Metode Penelitian

Gambaran Umum

Metode yang digunakan dalam perencanaan fasilitas rekreasi kolam retensi di Kelurahan Muktiharjo Kidul adalah kuantitatif dan kualitatif. Fokus dari penelitian kuantitatif adalah survey atau eksperimen dengan mereflesikan asumsi pospositivisme. Sedangkan metode kualitatif, digunakan untuk melakukan observasi secara naturalistik, sehingga nantinya didapatkan gambaran untuk menyusun perancangan. Alasan pemilihan metode ini adalah untuk mengetahui kondisi dan karakteristik dari studi yang dilakukan dengan melihat data-data yang selanjutnya dianalisis menggunakan analisis statistik untuk menguji hipotesis yang dilakukan. Pengolahan data tersebut dilakukan dengan menggunakan statistik deskrptif yang kemudian hasil dari pengolahan tersebut digambarkan tanpa bermaksud membuat kesimpulan yang berlaku untuk umum atau generalisasi.

Dalam melakukan pengumpulan data yang diperlukan, terdapat dua jenis data yaitu data primer dan data sekunder. Teknik pengumpulan data primer merupakan pengumpulan data yang dilakukan secara langsung oleh pengumpul data dengan menggunakan teknik-teknik pengumpulan seperti wawancara kepada pihak yang terkait, observasi dan kuesioner kepada masyarakat untuk melihat kondisi secara langsung.

Teknik sampling yang digunakan dalam penelitian dan perencanaan ini menggunakan teknik sampling purposive. Peneknan metode penelitian purposive ini adalah pada karakter anggota sampel yang karena pertimbangan mendalam dianggap/ diyakini oleh peneliti akan benar-benar mewakili karakter populasi/ subpopulasi (Yunus, 2010). Teknik sampling purposive ini difokuskan pada pertimbangan untuk pemilihan populasi yang akan disurvei. Pertimbangan yang ditentukan harus dapat menjelaskan bahwa keterwakilan dari populasi tersebut sudah tepat dan layak dijadikan sebagai sampel. Sampling dilakukan pada ahli-ahli perencana yang mengetahui tentang kolam retensi, dinas-dinas yang terkait dalam pembangunan kolam retensi, masyarakat dan Kelurahan Muktiharjo Kidul yang menjadi target perencanaan fasilitas rekreasi pada kolam retensi tersebut.

Lokasi dari pembangunan kolam retensi Muktiharjo Kidul berada pada Utara dari Kelurahan Muktiharjo Kidul. Lokasi tersebut dibangunada lahan milik pemerintah Kelurahan Muktiharjo Kidul deng luas 5,4 Ha. Berdasarkan pada Perencanaan Kolam Retensi Muktiharjo Kidul yang dilakukan diperoleh beberapa fakta terkait perencanaan kolam retensi tersebut (Dinas Pengelolaan Sumber Daya Air Kota Semarang).

a. Kawasan yang didrain berada di bawah muka air Kali Tenggang pada kondisi air normal;

b. Sistem drainase kawasan studi terpengaruh air balik dari Kali Tenggang pada saat terjadi hujan;

c. Adanya lahan yang berpotensi untuk dijadikan kolam tampungan sementara meskipun sangat terbatas;

d. Kapasitas kali tenggang terbatas, tidak mampu menampung limpasan dari seluruh daerah tangkapan air.

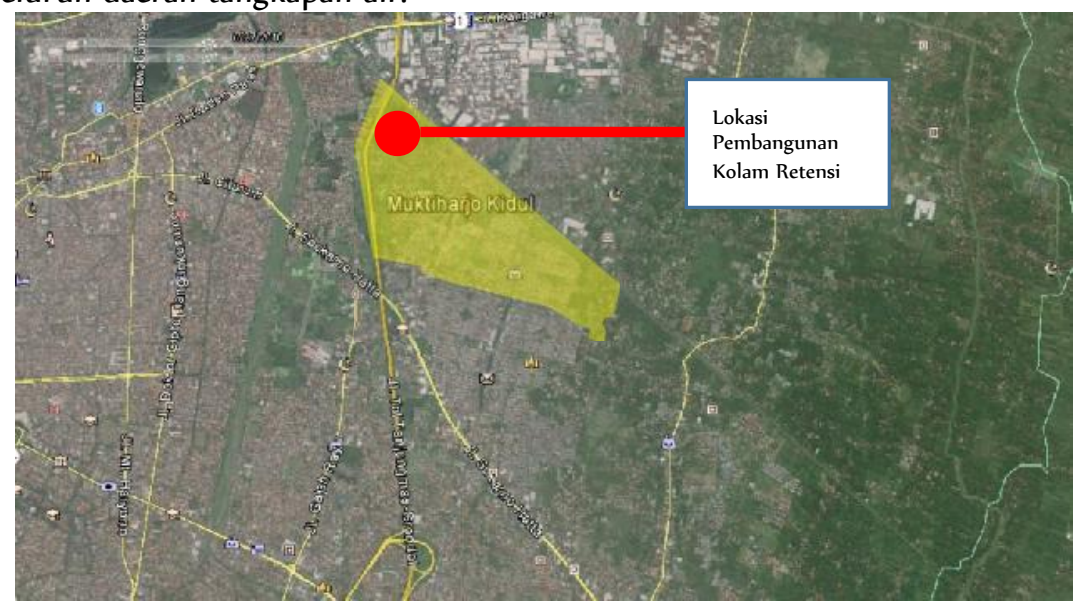

Gambar 1. Lokasi Pembangunan Kolam Retensi 
Pembangunan Kolam Retensi Muktiharjo Kidul memiliki beberapa komponen yang digunakan dalam mengoperasikannya. Komponen-komponen yang digunakan atau yang dibangun pada Kolam Retensi tersebut adalah Kolam Tampung, Pompa, Pintu Air, Saringan sampah, Tanggul keliling, Mercu pelimpah, Rumah penjaga, dan Pagar pengaman.

Pembangunan kolam retensi direncakan dengan beberapa data yang dijadikan untuk pembangunan kolam retensi tersebut. Pembangunan kolam retensi direncanakan dengan luas kolam retensi sebesar $58.000 \mathrm{~m}^{2}$ dengan kedalaman 3,5 $\mathrm{m}$. rencana kedalaman yang digunakan dengan kedalaman air maksimal yaitu $3 \mathrm{~m}$ dan kedalaman air normal $2 \mathrm{~m}$. sedangkan sisa dari kedalaman tersebut digunakan untuk cadangan untuk sedimen. Volume banjir yang terjadi pada kawasan tersebut adalah 235.547.200 liter. Dalam rencana tersebut dibangun Volume total dari Kolam retensi yaitu $203.000 \mathrm{~m}^{3}$ dan volume efektif pengendali banjir adalah $174.000 \mathrm{~m}^{3}$.

\section{Kajian Teori}

\section{Perencanaan dan Perancangan Kota}

Perencanaan merupakan suatu aktivitas universial manusia, suatu keahlian dasar dalam kehidupan yang berkaitan dengan pertimbangan suatu hasil sebelum diadakan pemilihan di antara berbagai alternatif yang ada (Catanese and Synder, 1996). Sedangkan perancangan kota pada dasarnya merupakan kegiatan untuk mengatur ruang kota agar ativitas kehidupan manusia dan lingkungan alam di sekitarnya berkembang secara harmonis dan bersifat lestari. Dalam perancangan kota terdapat tiga unsur penting dalam penataan ruang kota yaitu manusia, ativitas, dan fasilitas/area penunjang. Perancangan kota menurut Roger Trancik merupakan pengaturan unsur-unsur fisik lingkungan kota sehingga dapat berfungsi baik, ekonomis untuk dibangun, dan memberi kenyamanan untuk dilihat dan layak untuk hidup didalamnya (Mulyandari, 2011). Merancang adalah suatu tindakan untuk menstrukturkan ruang-ruang perkotaan, sehingga dapat tercipta tatanan, keindahan, dan skala. Perencanaan kota berfokus pada suatu proses yaitu rencana. Sedangkan perancangan kota lebih menekankan pada produknya yaitu desain.

\section{Pengertian Sistem Drainase dan Kolam Retensi}

Pada perencanaan dan pengembangan sistem drainase kota perlu kombinasi antara perkembangan perkotaan, daerah rural dan daerah aliran sungai (DAS). Untuk pengembangan suatu wilayah baru di perkotaan, perancangannya harus disesuaikan dengan sistem drainase alami yang sudah ada maupun yang telah dibuat (Kodoatie, 2003).

Fungsi dari drainase (Kodoatie, 2003) adalah:

- Membebaskan suatu wilayah (terutama yang padat pemukiman) dari genangan, erosi dan banjir.

- Karena aliran lancar maka drainase juga berfungsi memperkecil resiko kesehatan lingkungan; bebas dari malaria (nyamuk) dan penyakit lainnya

- Kegunaan tanah pemukiman padat akan menjadi lebih baik karena terhindar dari kelembaban

- Dengan sistem yang baik tata guna lahan dapat dioptimalkan dan juga memperkecil kerusakan-kerusakan struktur tanah untuk jalan dan bangunanbangunan lainnya.

Kolam retensi adalah prasarana drainase yang berfungsi untuk menampung dan meresapkan air hujan di suatu wilayah (Peraturan Menteri Pekerjaan Umum 2004). Poin utama dari definisi kolam retensi berkaitan dengan fungsinya adalah menampung dan meresapkan. Kedua fungsi tersebut saat ini juga banyak dikenal sebagai drainase yang berwawasan lingkungan karena memberikan kesempatan bagi air untuk menyerap ke tanah. Sebagai lahan resapan, salah satu syarat dari pembangunan kolam retensi adalah penentuan lokasi yang berada pada bagian terendah dari lahan keseluruhan. Secara teknis, untuk membangun sebuah kolam retensi membutuhkan data klimatologi, hidrologi, daerah genangan, faktor penyebab banjir, peta dasar, jaringan jalan, tata guna lahan, peta kawasan permukiman sekitar, topografi, serta data kependudukan. 


\section{Ruang Publik Sebagai Elemen Perancangan Kota}

Ruang-ruang yang berada di antara bangunan disebut dengan ruang publik. Ruang publik merupakan ruang terbuka yang mampu menampung kebutuhan akan tempat-tempat pertemuan dan aktivitas bersama. Ruang tersebut memungkinkan terjadinya pertemuan antar manuasia untuk saling berinteraksi. Urban design plan di San Francisco tahun 1970 berusaha menghubungkan 4 kelompok ruang-ruang diantaranya: bentuk dan kesan secara internal; bentuk dan kesan secara eksternal; parkir dan sirkulasi yang lebih berkaitan dengan melihat jalan dan karakteristiknya baik dari aspek kualitas perawatan, luasan, susunan, kemonotonan, kejelasan dari rute, orientasi ke tujuan, aman, kemudahan sirkulasi, persyaratan parkir dan lokasinya; kualitas lingkungan (quality of environment) (Shirvani, 1985).

\section{Pengertian Rekreasi}

Rekreasi berasal dari bahasa latin yaitu "creature" yang berarti mencipta, lalu diberi awalan "re" yang berarti "pemulihan daya cipta atau penyegaran daya cipta". Kegiatan rekreasi biasanya dilakukan di waktu senggang yang bertujuan untuk membentuk, meningkatkan kembali kesegaran fisik, mental, pikiran dan daya rekreasi (baik secara individual maupun secara kelompok) yang hilang akibat aktivitas rutin sehari-hari dengan jalan mencari kesenangan, hiburan dan kesibukan yang berbeda dan dapat memberikan kepuasan dan kegembiraan yang ditujukan bagi kepuasan lahir dan batin manusia (Karyono, 1997).

\section{Kebutuhan Fasilitas Rekreasi}

Kolam retensi yang termasuk pada sistem saluran drainase menjadi perhatian dalam mengatasi masalah banjir yang sering terjadi di Kelurahan Muktiharjo Kidul. Adanya kolam retensi seluas $5,4 \mathrm{Ha}$ menjadi salah satu potensi untuk mengembangkan lokasi tersebut sebagai ruang publik yang juga dapat dimanfaatkan sebagai fasilitas rekreasi. Berdasarkan survei yang telah dilakukan didapatkan hasil bahwa mayoritas masyarakat yang berada pada Kelurahan Muktiharjo Kidul merasa bahwa masih belum adanya pemenuhan akan fasilitas rekreasi. Banyak dari masyarakat yang berada di Kelurahan Muktiharjo Kidul yang mencari fasilitas lain menuju ke wilayah lain. Pemenuhan fasilitas rekreasi pada wilayah Kelurahan Muktiharjo Kidul dirasa perlu untuk memberikan ruang bagi masyarakat bersosialisasi dan mengisi kegiatan sehari-hari dengan positif. Penerimaan warga terhadap rencana pembangunan fasilitas rekreasi cukup tinggi karena merupakan hal yang baru di lingkungan tempat tinggalnya. Menurut hasil penyebaran kuesioner didapatkan bahwa $90 \%$ masyarakat setuju dengan adanya pembangunan fasilitas rekreasi pada kolam retensi. Harapannya dengan dibangun fasilitas rekreasi pada kolam retensi dapat menjadi alternatif baru dan lokasi pilihan untuk kegiatas rekreasi.

\section{Lokasi Pembangunan Kolam Retensi}

Pihak Pemerintah yaitu PSDA Kota Semarang membangun kolam retensi dengan tujuan untuk mengurangi permaslaahan banjir yang terdapat di Kelurahan Muktiharjo Kidul. Lokasi yang ditentukan pemerintah pada Kelurahan Muktiharjo Kidul terdapat dua titik yaitu Pond Muktiharjo Kidul dan Pond Tlogomulyo. Kajian penelitan lokasi tersebut ditentukan dengan menggunakan kriteria yang telah didapat sehingga dirumuskan indikator dalam pemilihan lokasi tersebut dengan menggunakan kepemilikan lahan, topografi, kemudahan lokasi, sistem drainase (sungai), daerah cekungan, tangkapan yang besar, dan elevasi muka tanah rendah dari pada muka banjir. Berdasarkan indikator tersebut didapatkanlah bobot lebih baik berada di titik Pond Muktiharjo Kidul. Hal ini membuktikan bahwa keefektifan pada Pond Muktiharjo Kidul lebih baik dalam mengatasi atau mengurangi permasalahan banjir. Sehingga titik pembangunan yang dilakukan oleh pihak PSDA sudah sesuai dengan kondisi yang ditemukan.

\section{Strategi Perencanaan}

Strategi yang perlu dilakukan dalam pembangunan kolam retensi ini dapat mengarahakan dalam perencanaan yang dilakukan sehingga tepat sasaran. Strategi 
yang dilakukan yaitu dengan terpenuhinya kriteria yang digunakan dalam penentuan lokasi kolam retensi pembangunan tersebut sebagai upaya dalam menanggulangi banjir. Pengoperasian dan pengelolaan melibatkan kerjasama antar pemerintah dan masyarakat agar kinerja dari sistem drainase dapat berjalan dengan baik. Diperlukannya peningkatan kesadaran masyarakat untuk mengurangi resiko banjir. Perencanaan kolam retensi sebagai fasilitas rekreasi dapat menimbulkan dampak yang cukup baik bagi masyarakat sekitar. Selain itu juga operasional fasilitas rekreasi merupakan wewenang pemerintah dan dikerjakan oleh masyarakat. Dengan begitu, strategi yang didapat dapat membangun masyarakat sekitar dan juga memenuhi kebutuhan dari masyarakat tersebut.

\section{Justifikasi Konsep dan Perencanaan}

Pada saat ini ruang publik semakin berkurang setiap waktunya. Banyaknya alih fungsi lahan yang tidak terkendali menyebabkan ruang publik sering kali beralih fungsi. Keberadaan ruang publik pada permukiman seharusnya merupakan kebutuhan mendasar yang harus ada dan disediakan bagi masyarakat. Proporsi ruang terbuka hijau pada suatu wilayah paling sedikit $30 \%$ dari luas wilayah tersebut (Undang-Undang Nomor 26 Tahun 2007 Tentang Penataan Ruang). Pesatnya pembangunan permukiman seharusnya di imbangi dengan penyediaan ruang publik. Namun pada kenyataannya, ruang publik menjadi semakin sulit untuk ditemukan.

Begitu juga yang terjadi di Kelurahan Mutkiharjo Kidul, wilayah ini merupakan salah satu wilayah padat permukiman. Namun pada wilayah ini sangat minim untuk ditemukan adanya ruang publik. Masyarakat di Kelurahan Muktiharjo Kidul pun merasa bahwa jumlah ruang publik untuk dapat dimanfaatkan sebagai fasilitas rekreasi belum terdapat pada wilayah ini.

Berdasarkan hal tersebut perlu adanya pemanfaatan ruang publik yang ditujukan untuk masyarakat. Pemanfaatan ruang publik tersebut akan direncanakan pada lokasi kolam retensi yang memiliki luasan 5,4 Ha. Dengan luasan yang cukup besar, lokasi ini sangat cocok untuk direncanakan sebagai fasilitas rekreasi dan juga ruang publik yang dapat menampung aktivitas masyarakat yang terdapat pada kawasan permukiman di Kelurahan Muktiharjo Kidul dan sekitarnya. Kolam retensi akan direncanakan sebagai pusat wisata air. Rekreasi pemancingan akan menjadi salah satu kegiatan yang terdapat pada wilayah ini karena merupakan salah satu kegiatan favorit dari masyarakat sekitar.

Konsep Waterfront As A Public Space And Recreational merupakan konsep yang lahir untuk menjawab permasalahan serta tujuan yang ingin dicapai. Tujuan tersebut yaitu memanfaatkan kolam retensi sebagai ruang publik dan pusat rekreasi di Kelurahan Muktiharjo Kidul yang juga berfungsi untuk meningkatkan fungsi dan nilai dari kawasan tersebut. Teori yang diambil untuk mendukung terwujudnya konsep tersebut adalah waterfront development dan child friendly space. Pada Waterfront Development terdapat jenis aktivitas yang dapat di terapkan berupa Recreational Waterfront dan Mix Use Waterfront. Recreational waterfront merupakan kawasan tepian air dengan dominasi aktivitas rekreasi di dalamnya sedangkan Mixed Use waterfront merupakan fasilitas waterfront yang paling umum dengan fungsi pendukung kegiatan yang beraneka ragam dengan menggabungkan fungsi perdagangan, perumahan, rekreasi, pariwisata dan olahraga. Konsep child friendly space merupakan konsep dimana tersedianya ruang publik yang memberikan keamanan dan kenyamanan bagi anak-anak dan kebebasan bagi anakanak untuk bermain (Farida, 2014).

Perhitungan kapasitas untuk masyarakat yang dapat berkunjung ke fasilitas rekreasi dihitung menggunakan standar yang terdapat pada Pedoman Standar Pelayanan Minimal Bidang Penataan Ruang, Perumahan dan Permukiman dan Pekerjaan Umum (Keputusan Menteri Permukiman dan Prasarana Wilayah No. 534/KPTS/M/2001 2001).

Pada peraturan tersebut terdapat bidang pelayanan sarana ruang terbuka yang menjelaskan tingkat pelayanan yaitu $0,3 \mathrm{~m}^{2} /$ penduduk dari luas kawasan. Jadi perhitungan untuk kapasitas pengguna menggunakan standar dari peraturan tersebut. Diketahui: 


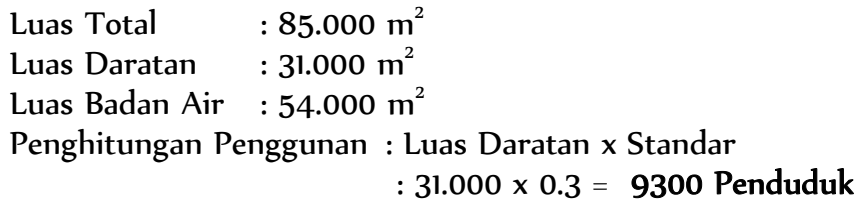

\section{Penerapan Konsep}

Konsep yang akan di terapkan pada lokasi perancangan adalah Waterfront As A Public Space And Recreation. Berdasarkan beberapa best practice yang telah di ambil, berikut merupakan penerapan konsep pada lokasi perancangan:

1. Konsep yang di ambil untuk lokasi perancangan yaitu Waterfront As A Public Space And Recreation. Berdasarkan konsep tersebut maka lokasi kolam retensi akan di kembangkan sebagai fasilitas rekreasi dan juga ruang publik bagi masyarakat sekitar. Konsep waterfront merupakan pengembangan suatu kegiatan yang terdapat pada tepian air serta pada bagian air itu sendiri. Konsep pada lokasi perancangan juga di adaptasi dari teori mengenai recreational waterfont serta mixed use waterfront dimana pemanfaatan kolam retensi nantinya akan di gunakan sebagai sarana rekreasi yang di dalamnya terdapat juga sarana perdagangan, sarana olahraga serta sarana penunjang lainnya.

2. Selain itu lokasi perancangan juga mengadaptasi teori lain yaitu child friedly space dimana ruang publik adalah lingkungan sosial yang di tujukan bagi perkembangan anak. Berdasarkan teori tersebut maka perlu adanya suatu ruang publik yang dapat memberikan suatu kebebasan bermain, keamanan dalam melakukan kegiatan, sarana untuk berkegiatan bersama keluarga serta lingkungan yang terbebas dari polusi bagi anak-anak. Pada lokasi perancangan terdapat taman bermain bagi anak-anak yang lokasinya berada tidak dekat dengan kolam retensi, sehingga akan memberikan keamanan bagi anak-anak untuk bermain. Selain itu terdapat pepohonan yang teduh sepanjang lokasi perancangan yang dapat memberikan kenyamanan serta kebebasan dari polusi udara. Selain permainan, pada lokasi perancangan juga terdapat rumah edukasi yang berupa perpustakaan umum sehingga selain bermain anak-anak juga dapat meningkatkan wawasan saat berada pada lokasi perancangan.

3. Bagi masyarakat yang hobi memancing, pada lokasi perancangan akan terdapat spot-spot untuk pemancingan. Area pemancingan tersebut berupa tempat berbentuk setengah lingkaran yang sedikit menjorok ke kolam yang berfungsi sebagai tempat duduk bagi para pemancing. Terdapat 10 area pemancingan yang berada di area kolam retensi. Pada setiap lokasi pemancingan terdapat fasilitas seperti lampu penerangan, kursi taman, serta tempat sampah. Selain itu di setiap area pemancingan terdapat pohon ketapang yang memberikan keteduhan dan kenyamanan bagi para pemancing.

4. Selain pemancingan terdapat permainan perahu becak air yang juga merupakan fasilitas rekreasi yang memanfaatkan kolam retensi sebagai wadahnya. Permainan perahu becak air ini lebih ditujukan untuk anak-anak yang berkunjung ke lokasi perancangan. Namun bagi pengunjung dewasa juga dapat menikmati permainan ini.

5. Landmark pada perancangan berupa tulisan Taman Rekreasi Muktiharjo Kidul. Tulisan Taman Rekreasi Muktiharjo Kidul dipilih agar masyarakat mudah mengetahui bahwa kolam retensi akan berfungsi sebagai lokasi sarana rekreasi. Selain itu kolam retensi itu sendiri merupakan landmark alami yang terbentuk karena adanya aktivitas rekreasi di dalamnya.

6. Jalur pejalan kaki yang juga berfungsi sebagai jogging track dan juga jalan inspeksi memiliki lebar 4 meter. Sepanjang sisi jalur pejalan kaki dilengkapi dengan peneduh berupa pepohonan. Selain itu juga sepanjang jalur tersebut di lengkapi dengan lampu penerangan jalan, kursi taman, dan juga tong sampah.

7. Jalur pejalan kaki ini berbahan paving blok sehingga memberikan kenyamanan bagi masyarakat yang ingin sekedar berjalan kaki atau berolahraga.

8. Terdapat sarana perdagangan berupa kios-kios yang di lengkapi dengan meja dan kursi bagi pengunjung yang ingin beristirahat serta menikmati makanan di lokasi perancangan. Tersedia 14 unit kios perdagangan bagi para pengunjung. Selain 
menyediakan makanan, akan terdapat kios khusus yang menjualkan umpan bagi masyarakat yang ingin memancing.

9. Terdapat pelataran yang digunakan untuk interaksi sosial bagi masyarakat. Area ini dapat digunakan bagi komunitas-komunitas sebagai tempat berkumpul, atau acara-acara massal seperti senam bersama.

10. Bagi pengunjung yang gemar berolahraga juga di sediakan sarana olahraga yaitu berupa lapangan voli dan badminton. Jadi bagi pengunjung yang hobi bermain voli atau badminton dapat memanfaatkan area ini, selain itu juga terdapat area jogging track bagi pengujung yang sekedar ingin berolahraga biasa.

11. Ruang edukasi di bangun untuk memberikan wawasan bagi pengunjung mengenai bahaya banjir dan dampak buruk dari banjir. Selain itu juga ruang edukasi ini nantinya berupa perpustakaan yang memberikan pengetahuan umum lainnya.

12. Sarana penunjang yang terdapat pada lokasi perancangan berupa halaman parkir dan juga toilet umum. Halaman parkir terbagi 2 lokasi yaitu terdapat pada bagian utara dan selatan. Untuk bagian utara hanya terdapat parkir untuk roda dua, sedangkan untuk di bagian selatan terdapat parkir untuk roda dua dan roda empat. Di sisi-sisi area parkir roda empat terdapat pepohonan untuk memberikan keteduhan sehingga tetap memberikan kenyamanan pada area parkir roda empat. Untuk area parkir roda dua juga terdapat atap peneduh untuk menambah kenyamanan. Terdapat 3 unit toilet umum yang di pisahkan antara untuk pria dan wanita. Toilet umum berada di bagian utara, selatan dan juga dekat area olahraga.

13. Pada lokasi perancangan terdapat tong-tong sampah yang tersebar di setiap kawasan sehingga mencegah pembuangan sampah yang sembarangan. Tong sampah terbagi menjadi 2 jenis yaitu untuk sampah organik dan non organik. Selain itu juga terdapat TPS kecil yang berfungsi untuk tempat pengumpulan sampah sementara yang berada pada ujung lokasi perancangan, sehingga meminimalisir polusi yang di hasilkan serta pemandangan yang kurang baik.

14. Kolam retensi termasuk kedalam ketegori wilayah sungai bertanggul yang berada di dalam perkotaan. Oleh karena itu kolam retensi ini harus memiliki garis sempadan sungai, jadi garis sempadan sungai minimalnya berjarak 3 meter sepanjang sisi-sisi kolam retensi. Pada bagian selatan, utara dan timur lokasi perancangan, garis sempadan sungainya memiliki jarak 10 meter. Jarak tersebut digunakan agar antara kolam retensi dan wilayah di sekitarnya memiliki batasan wilayah. Sedangkan untuk lokasi perancangan bagian barat, garis sempadan sungainya dibuat dengan jarak 35 meter. Hal ini dikarenakan pada bagian barat lokasi perancangan bersebelahan dengan jalan tol, maka garis sempadan sungai lebih di perbanyak karena selain berfungsi sebagai zona penyangga, garis sempadan sungai juga berfungsi sebagai pelindung dari kebisingan dan polusi yang dihasilkan dari jalan tol tersebut. Vegetasi yang terdapat pada lokasi perancangan berupa pohon ketapang dan mahoni. Pohon ketapang berfungsi untuk mengurangi kebisingan dan pohon mahoni berfungsi untuk memberi keteduhan di lokasi perancangan. Selain itu sepanjang zona penyangga beralaskan rumput hijau.

\section{Kesimpulan dan Rekomendasi}

\section{Kesimpulan}

Kelurahan Muktiharjo Kidul merupakan salah satu lokasi yang ditetapkan oleh pemerintah untuk dijadikan sebagai lokasi kolam retensi dalam RKPD tahun 2014. Lokasi yang ditentukan dari pemerintah sebelumnya terdapat pada dua titik yaitu pada Pond Muktiharjo Kidul dan Pond Tlogomulyo. Berdasarkan kajian ulang penentuan lokasi ditentukan lah indikator-indikator penentuan lokasi kolam retensi. Dari dua titik lokasi tersebut didapatlah lokasi yang lebih baik yaitu berada di pond Muktiharjo Kidul. Pond Muktiharjo Kidul memiliki keefektifan yang lebih baik dalam mengatasi banjir dan kesesuaian lokasi yang lebih memungkinkan untuk dibangun kolam retensi dibandingkan pada Pond Tlogomulyo.

Kolam retensi memiliki lahan seluas $5,4 \mathrm{Ha}$, luasan tersebut sangat disayangkan apabila tidak dimanfaatkan dengan baik. Oleh karena itu 
direncanakanlah pembangunan ruang publik dan fasilitas rekreasi agar kolam retensi tidak bersifat fungsional.

Pengembangan kolam retensi didapatkan berdasarkan bestpractice dari Taman Prestasi Surabaya, Taman Lansia Bandung, Hutan Kota Srengseng, dan Setu Babakan. Selain kolam retensi di Kelurahan Muktiharjo Kidul, Kota Semarang sudah memiliki bangunan pengendali banjir lainnya yaitu Polder Tawang yang sudah berdiri dari tahun 2009. Polder tawang memiliki luas 1,3 $\mathrm{Ha}$ dengan daerah tangkapan kurang lebih $70 \mathrm{Ha}$. Polder tawang telah dijadikan masyarakat sebagai salah satu ruang publik yang ada di Kota Semarang. Polder Tawang selain berfungsi sebagai kolam penampungan air, juga menjadi salah satu sarana alternatif rekreasi yang dibentuk oleh masyarakat.

Pada awal pembangunannya, polder tawang dikembangkan sendiri oleh masyarakat dengan adanya rekreasi air, namun karena sebelumnya tidak adanya perencanaan untuk dijadikan sebagai area ruang publik dan rekreasi menyebabkan tidak terkelolanya area polder tawang. Berdasarkan kondisi tersebut, maka perlu adanya perencanaan fasilitas rekreasi dan ruang publik pada kolam retensi di Kelurahan Muktiharjo Kidul agar pengelolaannya menjadi lebih baik dan terarah. Berdasarkan bestpractice dan contoh praktis dari beberapa kota yang ada di Indonesia maka munculah konsep Waterfront As A Public Space And Recreation. Dengan adanya fasilitas rekreasi dan ruang publik pada kolam retensi, maka masyarakat dapat memenuhi kebutuhan akan aktivitas rekreasi tanpa harus menempuh jarak yang jauh, selain itu masyarakat juga dapat meningkatkan perekonomian karena berkurangnya banjir akibat kolam retensi dan karena adanya pusat aktivitas pada kolam retensi seperti perdagangan, dan aktivitas pemancingan yang hasilnya dapat dipergunakan oleh masyarakat.

\section{Rekomendasi}

1. Rekomendasi Bagi Pemerintah

- Perlunya penataan kembali perumahan di sekitar kawasan kolam retensi sehingga kawasan kolam retensi dapat lebih tertata dengan baik dan dapat berfungsi sebagai bangunan pengendali banjir serta sebagai penyedia ruang publik dan fasilitas rekreasi.

- Perlu adanya pelebaran jalan yang sebelumnya berjarak 3 meter menjadi 4 meter. Jalan tersebut berfungsi sebagai jalan inspeksi, oleh karena itu jarak minimal jalan inspeksi yaitu 4 meter (Peraturan Menteri Pekerjaan Umum Republik Indonesia Nomor 17/PRT/M/2011).

- Perlu adanya upaya untuk memberikan kesadaran bagi masyarakat dalam memelihara dan menjaga semua fasilitas yang terdapat pada lokasi kolam retensi.

- Pemerintah bersama masyarakat juga harus mampu bekerja sama untuk saling memelihara dan mengelola lokasi kolam retensi agar kedepannya dapat meningkatkan fungsi dari kawasan dan memberikan manfaat bagi masyarakat sekitar.

2. Rekomendasi Bagi Masyarakat

- Perlunya kesadaran bagi masyarakat untuk menjaga lingkungan dan merubah perilaku mereka dalam membuang sampah sembarangan. Perilaku masyarakat sangat berpengaruh dengan perkembangan fasilitas rekreasi yang ada pada kawasan. Dengan perilaku yang baik maka fasilitas rekreasi pada kolam retensi dapat memberikan manfaat bagi masyarakat sekitar.

- Masyarakat harus ikut serta dalam menjaga kebersihan serta pengelolaan kawasan fasilitas rekreasi. Dengan adanya pengelolaan yang baik, maka kawasan tersebut akan dapat mengembangkan fungsi dari kawasan itu sendiri dan kawasan di sekitarnya.

- Perlunya kesadaran masyarakat bahwa kawasan kolam retensi bukan hanya berfungsi sebagai ruang publik dan rekreasi melainkan memiliki fungsi utama sebagai bangunan pengendali banjir. Oleh karena itu perlu adanya pengelolaan persampahan dan kawasan dengan maksimal. 
Daftar Pustaka
Catanese, A. J, dan Synder, J. C. 1996. Perencanaan Kota, Edisi Kedua. Jakarta: Erlangga. Dinas Pengelolaan Sumber Daya Air Kota Semarang.

Farida, A. 2014. "Penerapan Konsep Child Friendly Space Pada Ruang Publik Kampung Badran Yogyakarta." Skripsi Program Studi Pendidikan Seni Rupa Universitas Negeri Yogyakarta.

Karyono, H. 1997. Kepariwisataan. Jakarta: Gramedia Widia Sarana Indonesia.

Keputusan Menteri Permukiman dan Prasarana Wilayah No.534/KPTS/M/2001.

Kodoatie, R.j. 2003. Pengantar Manajemen Infrastruktur. Semarang: Pustaka Pelajar.

Mulyandari, H. 2011. Pengantar Arsitektur Kota. Yogyakarta : ANDI.

Peraturan Menteri Pekerjaan Umum No 12 Tahun 2004 Tentang Penyelenggaraan Sistem Drainase Perkotaan.

Peraturan Menteri Pekerjaan Umum Republik Indonesia Nomor 17/PRT/M/2011 Tentang Pedoman Penetapan Garis Sempadan Jaringan Irigasi.

Peraturan Walikota Semarang No.17 Tahun 2013 Tentang Rencana Kerja Pembangunan Daerah (RKPD) Kota Semarang Tahun 2014.

Shirvani, H. 1985. The Urban Design Process. New York: Van Nostrand Reinhold Company.

Undang-Undang Nomor 26 Tahun 2007 Tentang Penataan Ruang.

Yunus, H.S. 2010. Metodologi Penelitian Wilayah Kontemprorer. Yogyakarta: Pustaka Pelajar. 